\title{
Examination of the Knowledge Levels, Attitudes and Anxiety Sources Regarding Coronavirus Disease-2019 Infection in Dentistry Students in Clinical Practice
}

\author{
Klinik Uygulama Yapan Diş Hekimliği Fakültesi Öğrencilerinin \\ Koronavirüs Hastalığı-2019 ile Ilgili Bilgi Düzeylerinin, \\ Tutumlarının ve Kaygı Kaynaklarının Incelenmesi
}

\author{
(D) Hümeyra Tercanlı Alkış ${ }^{1}$, (D Selin Yeşiltepe ${ }^{2}$, (D) Elif Kurtuldu ${ }^{3}$ \\ 1Akdeniz University Faculty of Dentistry, Department of Dentomaxillofacial Radiology, Antalya, Turkey \\ ${ }^{2}$ Aydın Adnan Menderes University Faculty of Dentistry, Department of Dentomaxillofacial Radiology, Aydın, Turkey \\ ${ }^{3}$ Sakarya Oral and Dental Health Hospital, Clinic of Oral, Dental and Maxillofacial Radiology, Sakarya, Turkey
}

Keywords

Dentistry, education, COVID-19

Anahtar Kelimeler

Diş hekimliği, eğitim, COVID-19

Received/Geliş Tarihi : 13.11.2020 Accepted/Kabul Tarihi : 01.02.2021

doi:10.4274/meandros.galenos.2021.97769

Address for Correspondence/Yazışma Adresi: Elif Kurtuldu MD,

Sakarya Oral and Dental Health Hospital, Clinic of Oral, Dental and Maxillofacial Radiology, Sakarya, Turkey

Phone : +90 5352131657

E-mail : ekurtuldu93@gmail.com

ORCID ID: orcid.org/0000-0003-4844-4906

(C) Meandros Medical and Dental Journal, Published by Galenos Publishing House.

This is article distributed under the terms of the Creative Commons Attribution NonCommercial 4.0

International Licence (CC BY-NC 4.0).

\begin{abstract}
Objective: This study aimed to examine and evaluate the knowledge levels, attitudes and anxiety sources regarding coronavirus disease-2019 (COVID-19) infection in dentistry students in clinical practice.

Materials and Methods: Fourth- and fifth-year dentistry students of Aydın Adnan Menderes University and Akdeniz University were selected for this study. For data collection, a questionnaire survey was performed. The questionnaire contained 34 items on demographic data, knowledge level about COVID-19 infection and attitudes and anxiety sources about their education. Descriptive statistical methods and the Pearson chi-square test were used to analyse data. $\mathrm{P}<0.05$ was statistically significant.

Results: A total of 137 students, including 75 females (54.7\%) and 62 males (45.3\%), participated in the study. Significantly higher levels of negativity and anxiety due to COVID-19 was found in female participants than in male participants, based on their responses to the following questions: "Do you believe that the lack of face-toface training due to COVID-19 will negatively affect your working life?"; "Do you worry about graduating having completed clinical practice without direct patient care?"; "Do you worry about practising your job because of the coronavirus?" and the $p$ values were found $0.019,0.002$ and 0.009 , respectively. The answers for these questions were not related to the graduation degree.

Conclusion: The results reveal that female students demonstrated higher stress levels than male students based on the responses to some questions. Moreover, responses to the same questions were not related to the graduation degree. Further larger studies will give more accurate outcomes.
\end{abstract}

Öz

Amaç: Bu çalışmada yazarlar, klinik uygulama yapan diş hekimliği fakültesi öğrencilerinin koronavirüs hastalığı-2019 (COVID-19) enfeksiyonu ile ilgili bilgi düzeylerini, tutumlarını ve kaygı kaynaklarını incelemeyi ve değerlendirmeyi amaçlamaktadır. 
Gereç ve Yöntemler: Aydın Adnan Menderes Üniversitesi ile Akdeniz Üniversitesi, Diş Hekimliği Fakülteleri dördüncü ve beşinci sınıf öğrencileri bu çalışma için seçildi. Veri toplamak için bir anket kullanıldı ve bu anket demografik sorular, COVID-19 hakkında bilgi seviyesi soruları ve eğitim sürecindeki kaygı kaynakları ve tutum ile ilgili 34 sorudan oluşmaktaydı. Veriler, tanımlayıı istatistiksel yöntemler ve Pearson ki-kare testi kullanılarak analiz edildi, $p<0,05$ istatistiksel olarak anlamlı kabul edildi.

Bulgular: Çalışmaya, 75 kadın $(\% 54,7), 62$ erkek $(\% 45,3)$ olmak üzere toplam 137 katılımcı dahil edildi. Kadınların COVID-19 nedeniyle yaşadıkları olumsuzluklar ve anksiyete, "COVID-19 sebebiyle yüz yüze eğitimin yapılamamasının çalışma hayatına geçince olumsuz etkileri olacağına inanıyor musunuz?", "Doğrudan hasta bakımı olmadan klinik uygulamaları tamamlayarak mezun olmaktan endişe duyuyor musunuz?", "Koronavirüs sebebiyle mesleğinizi uygulamaktan endişe duyuyor musunuz?" sorularında erkeklerden istatistiksel olarak anlamlı derecede yüksek ve $p$ değerleri sırasıyla 0,019, 0,002 ve 0,009 olarak bulundu. Aynı sorulara verilen cevapların mezuniyet derecesi ile ilişkisi bulunmadı.

Sonuç: Bazı sorulara verilen cevaplara göre kız öğrencilerin erkek öğrencilere göre daha stresli olduğu görüldü. Öte yandan aynı sorulara verilen cevapların mezuniyet derecesi ile ilgili olmadığı görüldü. Daha geniş kapsamlı çalışmalar konu ile ilgili daha detaylı bilgiler edinmemizi sağlayacaktır.

\section{Introduction}

A new outbreak of coronavirus occurred in December 2019 in Wuhan and quickly spread across China and other states in the world. Patients who presented at the hospital in Wuhan, China in midDecember of 2019 with headache, fever, dry cough, shortness of breath, and weakness were previously considered to be atypical pneumonia cases. However, some patients developed complications, such as respiratory failure, as the disease progressed and ventilation support was needed (1).

When the first case of such pneumonia was detected on December 12, influenza, other coronaviruses, and other diseases were excluded by laboratory tests, and on January 7, 2020, it was announced that a newly discovered coronavirus strain was isolated in these patients. On January 12, 2020, this virus was named as the 2019 novel coronavirus. The pneumonia caused by the new coronavirus was named by the World Health Organization (WHO) as coronavirus disease-2019 (COVID-19) on February 11, 2020, and this virus was renamed by the International Taxonomy Committee of Viruses [severe acute respiratory syndrome coronavirus 2 (SARS-CoV-2)] (2). Previously, there have been outbreaks of coronavirus that have threatened public health, such as Middle East respiratory syndrome-CoV and SARS-CoV (3).

Coronaviruses are RNA viruses known to cause hepatic, respiratory, and neurological disorders (4). Unlike other enveloped viruses, the envelope of the coronavirus is derived from the host cell endoplasmic reticulum. This difference may be a factor that increases pathogenicity (5).
The spread and consequences of the outbreak have affected the whole population, causing widespread public health concerns. Faculty of dentistry students are also indirectly or directly associated with such outbreaks. If adequate precautions are not taken, the environments in which dentists work can potentially cause cross-contamination. Therefore, they need to know more and gain a better insight into such diseases. After the first COVID-19 case was detected in Turkey in March 2020, face-to-face education was interrupted in all universities, and clinical training was also suspended in addition to faceto-face education in departments such as dentistry and medicine. While theoretical education continued on the e-learning platform of the universities, clinical training could not be continued with conventional methods in these departments. Universities regulated the clinical training activities into the presentation of case reports, interactive-learning tutorials on the basis of clinical cases, and studying scientific articles. Even though clinical training has continued with different activities on the e-learning platform, these activities cannot replace direct patient care. This lacking of clinical training is planned to be recovered in the following semester.

In this study, the authors aimed to examine and evaluate the knowledge levels, attitudes and anxiety sources regarding the infection of COVID-19 of the dentistry faculty students who perform the clinical practice.

\section{Materials and Methods}

This descriptive study was performed with students of Aydın Adnan Menderes University, 
Faculty of Dentistry and Akdeniz University, Faculty of Dentistry, nearly five months after the outbreak of the pandemic in Turkey, between July 15 and August 15, 2020. This study was approved by the Clinical Research Ethics Committee of the Faculty of Medicine, Akdeniz University (decision no: KAEK-582, date: 22.07.2020), and the study was carried out in accordance with the ethical rules of the Declaration of Helsinki.

Data collection was done using a questionnaire, which was designed by the authors for this purpose through the "Google Forms" website. Fourth- and fifth-grade students, for whom face-to-face and clinical education including direct patient care have been interrupted under the COVID-19 pandemic, were chosen for this study and the students were informed about the survey. The questionnaire was delivered to the students via the smartphone application "WhatsApp" and there was an informative text about the study at the top of the questionnaire. In addition, beneath the informative text, there was a check box for the participants to agree to voluntarily participate in the study. The survey consists of 34 questions and three sections: 1) Demographic questions; 2) knowledge level questions about infection of COVID-19; and 3) questions related to attitudes and anxiety sources regarding their education/ professional choices. The students who volunteered and answered all questions in both universities were included in the study.

\section{Statistical Analysis}

The data were statistically analysed using the Statistical Package for the Social Sciences (SPSS) software (version 23.0, SPSS Chicago, USA). The data were expressed as number, mean \pm standard deviation, and percentage. Descriptive statistical methods and the Pearson chi-square test were used in the analysis of the data.

\section{Results}

A total of 137 participants, including 75 females (54.7\%), 62 males (45.3\%) were included in the study. Participants were between 21 and 29 years old, with a mean age of $22.89 \pm 1.1$ years. Sixty-six $(48.2 \%)$ of the participants were studying at Aydın Adnan Menderes University, Faculty of Dentistry and 71 (51.8\%) at Akdeniz University, Faculty of Dentistry. Fifty-six (40.9\%) of the participants were fourth-grade students and $81(59.1 \%)$ were in the fifth grade.

The distribution of the answers given by the participants to the questions evaluating their knowledge level of COVID-19 is shown in Table 1. According to Table 1, all participants said "true" to the following statements: "The common symptoms of COVID-19 infection include cough, fever, and

\begin{tabular}{|l|l|l|l|}
\hline $\begin{array}{l}\text { Table 1. The distribution of the answers given by the participants to the questions evaluating knowledge level about } \\
\text { coronavirus disease-2019 }\end{array}$ & True (n/\%) & False (n/\%) & Undecided (n/\%) \\
\hline & $135 / 98.5$ & $0 / 0$ & $2 / 1.5$ \\
\hline COVID-19 is a viral infection & $118 / 86.1$ & $12 / 8.8$ & $7 / 5.1$ \\
\hline $\begin{array}{l}\text { COVID-19 is transmitted through close contact with an infected person or } \\
\text { animal }\end{array}$ & $137 / 100$ & $0 / 0$ & $0 / 0$ \\
\hline $\begin{array}{l}\text { The common symptoms of COVID-19 infection include cough, fever, and } \\
\text { shortness of breath }\end{array}$ & $130 / 94.9$ & $2 / 1.5$ & $5 / 3.6$ \\
\hline $\begin{array}{l}\text { Headaches, muscle pain, loss of taste or smell are other symptoms of } \\
\text { COVID-19 }\end{array}$ & $17 / 12.4$ & $95 / 69.3$ & $25 / 18.2$ \\
\hline Antibiotics are the first step of the treatment & $136 / 99.3$ & $1 / 0.7$ \\
\hline Washing hands with soap and water helps prevent disease transmission & & $0 / 0$ \\
\hline $\begin{array}{l}\text { Individuals with chronic diseases are more at risk for complications than } \\
\text { healty individuals }\end{array}$ & $137 / 100$ & $0 / 0$ & $0 / 0$ \\
\hline Healthcare workers are more at risk than other workers & $137 / 100$ & $0 / 0$ & $0 / 0$ \\
\hline $\begin{array}{l}\text { Transmission of the virus can be prevented by following the isolation rules } \\
\text { given by the World Health Organization }\end{array}$ & $117 / 85.4$ & $6 / 4.4$ & $14 / 10.2$ \\
\hline $\begin{array}{l}\text { The prevalence of COVID-19 can be reduced by the active participation of } \\
\text { healthcare professionals in regular infection control programs }\end{array}$ & $119 / 86.9$ & $4 / 2.9$ \\
\hline n: Number of participants, CovID-19: Coronavirus disease-2019 & & $14 / 10.2$ \\
\hline
\end{tabular}


shortness of breath"; "Individuals with chronic diseases are more at risk of complications than healthy individuals"; and "Health-care workers are more at risk than other workers".

To the question "If the COVID-19 vaccine was available, would you use it?", 102 (74.5\%) participants answered "yes", 5 participants (3.6\%) answered "no" and 30 participants $(21.9 \%)$ answered "undecided". To the question "Are you concerned about someone in your family being infected?", 127 (92.7\%) participants answered "yes", 9 participants (6.6\%) answered "no" and 1 participant $(0.7 \%)$ answered "undecided".

The answers were distributed to the question "What is your source of information about the pandemic?" can be seen in Table 2 .
To the question "What are you most afraid of about the pandemic?", 21 (15.3\%) participants answered "being infected" and 116 participants (84.7\%) answered "infecting other people".

The distribution of the answers given by the participants to the questions evaluating their attitudes and anxiety sources regarding COVID-19 infection is shown in Table 3. The answers given to the following questions have a relationship with gender, and $p$ values are $0.041,0.019,0.002$ and 0.009 , respectively: "Considering we need to get used to living with viruses, are you hesitant about the choice of the department of speciality?"; "Do you believe that the lack of face-to-face training due to COVID-19 will have negative effects when it comes to your working life?";

\begin{tabular}{l|l|l|}
\hline $\begin{array}{l}\text { Table 2. The distribution of the answers given to the question “What is your source of information about the } \\
\text { pandemic?” }\end{array}$ & $\mathbf{n}$ \\
\hline & 88 & 17.4 \\
\hline The Health Ministry website & 48 & 9.5 \\
\hline The World Health Organization website & 118 & 23.3 \\
\hline Social media (Health Ministry, scientific board members etc.) & 67 & 13.2 \\
\hline Social media (friends or health workers) & 90 & 17.8 \\
\hline Television & 34 & 6.7 \\
\hline Newspaper & 61 & 12.1 \\
\hline Scientific publication/article & 506 & 100 \\
\hline Total & \\
\hline Because there are multiple responses, the number of participants exceeds the sample size, n: Number of participants \\
\hline
\end{tabular}

Table 3. The distribution of the answers given by the participants to the questions evaluating their attitude and anxiety about their education/work life

\begin{tabular}{|c|c|c|c|}
\hline & Yes (n/\%) & No $(n / \%)$ & Undecided (n/\%) \\
\hline $\begin{array}{l}\text { Do you believe that the lack of face-to-face training due to COVID-19 will } \\
\text { have negative effects when it comes to your working life? }\end{array}$ & $96 / 70.1$ & $21 / 15.3$ & $20 / 14.6$ \\
\hline $\begin{array}{l}\text { Do you believe that the lack of pratical training due to COVID-19 will have } \\
\text { negative effects when it comes to working life? }\end{array}$ & $117 / 85.4$ & $10 / 7.3$ & $10 / 7.3$ \\
\hline $\begin{array}{l}\text { Do you worry about clinical practice may be disrupted if the second wave of } \\
\text { COVID-19 occurs? }\end{array}$ & $116 / 84.7$ & $13 / 9.5$ & $8 / 5.8$ \\
\hline $\begin{array}{l}\text { Do you worry about graduating having completed clinical practices without } \\
\text { direct patient care? }\end{array}$ & $112 / 81.8$ & $15 / 10.9$ & $10 / 7.3$ \\
\hline $\begin{array}{l}\text { Do you think the distance education cause lack of teorical education in this } \\
\text { period? }\end{array}$ & $85 / 62$ & $42 / 30.7$ & $10 / 7.3$ \\
\hline Do you think dentists are in the risk group for COVID-19? & $133 / 97.1$ & $3 / 2.2$ & $1 / 0.7$ \\
\hline $\begin{array}{l}\text { Considering we need to get used to living with viruses, are you hesitant } \\
\text { about the choice of the department of speciality? }\end{array}$ & $26 / 19$ & $95 / 69.3$ & $16 / 11.7$ \\
\hline Do you worry about practising your job because of the coronavirus? & $85 / 62$ & $36 / 26.3$ & $16 / 11.7$ \\
\hline
\end{tabular}


"Do you worry about graduating having completed clinical practices without direct patient care?"; "Do you worry about practising your job because of the coronavirus?". On the other hand, the answers given to the same questions are not related to the graduation degree, and $p$ values are $0.522,0.9,0.599$, and 0.822 , respectively.

A total of 114 (83.2\%) of the participants knew about COVID-19 precautions in clinical practice and $110(80.3 \%)$ of the participants had not received any training regarding COVID-19.

\section{Discussion}

Despite the efforts of health-care organizations, the COVID-19 pandemic is still increasing due to the difficulty in containing infection and the spread type of the infection (6). Dental students, dentists, and assistant staff are more exposed to pathogens which are transmitted through blood, saliva, or other body fluids than the normal population (7). For this reason, the knowledge and attitudes of students performing clinical practices about infectious diseases are very important (8).

Several studies are investigating the attitudes of dental students and knowledge levels about infectious diseases (7,9-13). As a very new disease, COVID-19 spreads fast and the information about it is limited. There are some studies on COVID-19 and dentistry students in the literature (14-16). Brondani and Donnelly (14) conducted a study with all dental students of the third and fourth years in the dentistry geriatric module. Quadri et al. (15) conducted a state cross-sectional study with focus on dental interns, specialists, and assistant. On the other hand, Atas and Yildirim (16) aimed to evaluate the attitudes, knowledge, and clinical training of dental students regarding the COVID-19 pandemic in their study, with a total of 355 preclinical and clinical students. In the current study, the authors aimed to examine and evaluate the knowledge levels, attitudes and anxiety sources with regard to the COVID-19 infection of dentistry faculty students who perform clinical applications.

Symptoms of COVID-19 appear from 2 to 14 days after being exposed to the virus. Common symptoms include cough, fever, difficulty breathing, and shortness of breath. Also, there may be symptoms such as body aches, fatigue, chills, loss of smell and taste, sore throat, diarrhoea, and severe vomiting. While some patients show no symptoms, others may have a combination of symptoms. Individuals with elderly or people with main chronic diseases are at high risk in terms of complications $(17,18)$. The aerosols and droplets that occur during routine dental treatments are a possible transmission path for COVID-19 and the risk for dentists, dental students and dental assistant staff is high (19-21). This study gave us an idea of the primary awareness level of the disease of dentistry students performing clinical practice. In our study, all participants answered "true" to the following statements: "The common symptoms of COVID-19 infection include cough, fever, and shortness of breath"; "Individuals with chronic diseases are more at risk of complications than healthy individuals"; and "Health-care workers are more at risk than other workers".

In the current study, $69.3 \%$ of the students stated that antibiotics can not be used to treat the infection of COVID-19, while Atas and Yildirim (16) found a ratio of $80 \%$ in their study. The authors think this rate of $69.3 \%$ should be higher because $98.5 \%$ of the participants responded 'true' to the statement "COVID-19 infection is a viral infection".

Although the way coronaviruses are transmitted remains uncertain, the virus is believed to be initially transmitted through direct or indirect contact and respiratory aerosols. There is droplet transmission with close personal contact when a person is within one metre of someone with symptoms such as sneezing or coughing. Indirectly, the virus is transmitted by touching contaminated objects or the immediate environment used by the infected person $(22,23)$. In the current study, $99.3 \%$ of the participants answered "true" to the following statement: "Washing hands with soap and water helps prevent disease transmission"; $88.3 \%$ of them answered "true" to the statement: "Transmission of the virus can be prevented by following the isolation rules given by the WHO". This shows us that the majority of students are aware of the individual precautions they should take. In addition, the knowledge level is important for students with limited clinical experience to protect themselves, patients and staff from infectious diseases.

In the current study, to the question "What are you most afraid of about the pandemic?", 21 
(15.3\%) participants answered "being infected" and 116 participants $(84.7 \%)$ answered "infecting other people". In Atas and Yildirim's (16) study, the questions "Do you fear about being infected with COVID-19 as a professional health-care working at close range with the patient?" and "Do you fear about infecting any people or relatives around you regarding COVID-19 due to your closeness to the patient as a healthcare worker?" were asked and the percentage of a "yes" response was $82.3 \%$ and $93 \%$, respectively. In both studies, the participants were concerned about infecting other people in society. However, in the current study, participants were less worried about being infected with the virus. This situation is thought to be due to the differences in the time periods of when the studies were conducted. Atas and Yildirim's (16) study was conducted during the week following the first COVID-19 cases reported in Turkey. The current study was performed about five months following the first case was seen, and during this period, serious precautions were taken by the authorities to avoid spreading the epidemic throughout the country, and new information about the coronavirus was obtained from the science world.

To treat or prevent COVID-19 infection, there is currently no special antiviral drug, and patients are treated symptomatically. There are more than 200 vaccine candidates tracked worldwide. However, there is no clarity in the development of a highly immunogenic and safe COVID-19 vaccine (24). In the current study, to the question "If the COVID-19 vaccine was available, would you use it?" 102 (74.5\%) participants answered "yes", 5 participants (3.6\%) answered "no" and 30 participants (21.9\%) answered "undecided".

In the current study, $36.5 \%$ of the participants got information on the COVID-19 from social media (Health Ministry, scientific board members, etc. and friends or health workers), $17.8 \%$ from television, $17.4 \%$ from the website of the Ministry of Health and $12.1 \%$ from scientific publications/articles. In Ikhlaq et al.'s (25) study, 384 undergraduate medical students were included and main sources of coronavirus information were television and social media - 53.1\%, and $18 \%$, respectively. Social media is easily accessible and has a wide dispersal but it may also be the source of fake information. According to these results, today it is seen that obtaining information through social media accounts is widespread and students' awareness of scientific articles should be increased. The authors think that scientific articles should be given more importance in theoretical education, and students should be supported in this issue.

With the uncertainty associated with the epidemic, most universities and dental school activities have been suspended to minimize the transmission of the virus $(26,27)$. This means that education moved rapidly to online education and this was a relatively new practice in dental education. Despite the online distribution of most written material, direct contact between instructors, students, and patients is important both for developing clinical skills and promoting professionalism through interpersonal interactions (28). Therefore, it is normal for some students to be concerned about their clinical competence. The answers given to the following questions have a relationship with gender, and $p$ values are $0.041,0.019,0.002$ and 0.009 , respectively: "Considering we need to get used to living with viruses, are you hesitant about the choice of the department of speciality?"; "Do you believe that the lack of face-to-face training due to COVID-19 will have negative effects when it comes to your working life?"; "Do you worry about graduating having completed clinical practices without direct patient care?"; "Do you worry about practising your job because of the coronavirus?" In these questions, we saw that females had statistically significantly higher anxiety and negativity due to COVID-19 than males. On the other hand, it has been observed that the answers given to the same questions are not related to the graduation degree. In some previous studies, it has been shown that the psychological conditions of male and female students are similarly impacted by the COVID-19 pandemic $(16,29)$. It can be said that stressful periods more negatively affected female participants than male participants and there is an association between anxiety and this psychological condition (30). In many studies, female dental students are shown to be experience more stress than their male colleagues under normal conditions. It is thought that this is because female participants generally are stressed more intensely while male participants do not express their anxiety $(31,32)$.

The reason why authors preferred to include dentistry students who were performing clinical 
practices in the current study was that these students were in contact with patients for dental treatment and therefore thought their awareness of the risk of infection would be higher than pre-clinical students. Dentistry students experience increased patient contact throughout their clinical years, leading to them being at a higher risk of cross-infection (33). In the current study, to the question "Do you think dentists are included in the risk group for COVID-19 infection?" $97.1 \%$ of participants answered "yes". Although they think they are in the risk group, 69.3\% of them answered "no" to the following question: "Considering we need to get used to living with viruses, are you hesitant about the choice of the department of speciality?". The authors think that new outbreaks do not have a significant impact on students' choice of departments.

In the current study, 114 (83.2\%) of the participants knew about COVID-19 pandemic precautions in clinical practice and $110(80.3 \%)$ of the participants did not receive any training about COVID-19. Among healthcare professionals, dental health professionals are highly exposed to infection, with serious implications for routine dental practice. Therefore, undergraduate dental students should be trained. Infection control protocols and using protective facilities are extremely important for personal safety even in asymptomatic patients.

The presented study was conducted in only two universities, which is considered to be a limitation of the study. The authors' opinion is that more accurate results can be obtained in a larger sample size with the participation of other universities.

\section{Conclusion}

Given the fact that COVID-19 is not the first pandemic that humanity has faced throughout its history and will not be the only one, it is very important to specify the attitudes, knowledge levels, and sources of anxiety of dentistry students in order to improve and reorganize dental education methods. In the present study, female students were found to be more stressed than male students in the answers given to some questions. On the other hand it has been observed that the answers given to the same questions are not related to the graduation degree. Further larger studies will give more accurate outcomes.

\section{Ethics}

Ethics Committee Approval: This study was approved by the Clinical Research Ethics Committee of the Faculty of Medicine, Akdeniz University (decision no: KAEK-582, date: 22.07 .2020 ), and the study was carried out in accordance with the ethical rules of the Declaration of Helsinki.

Informed Consent: Fourth- and fifth-grade students, for whom face-to-face and clinical education including direct patient care have been interrupted under the COVID-19 pandemic, were chosen for this study and the students were informed about the survey.

Peer-review: Externally peer-reviewed.

\section{Authorship Contributions}

Concept: S.Y., H.T.A., E.K., Design: S.Y., H.T.A., E.K., Supervision: H.T.A., S.Y., E.K., Fundings: H.T.A., S.Y., E.K., Materials: H.T.A., S.Y., Data Collection or Processing: H.T.A., S.Y., Analysis or Interpretation: H.T.A., Literature Search: H.T.A., S.Y., E.K., Critical Review: H.T.A., S.Y., E.K., Writing: H.T.A., S.Y., E.K.

Conflict of Interest: No conflict of interest was declared by the authors.

Financial Disclosure: The authors declared that this study received no financial support.

\section{References}

1. Li Q, Guan X, Wu P, Wang X, Zhou L, Tong Y, et al. Early transmission dynamics in Wuhan, China, of novel coronavirusinfected pneumonia. N Engl J Med 2020; 382: 1199-207.

2. Sahin AR, Erdogan A, Agaoglu PM, Dineri Y, Cakirci AY, Senel ME, et al. 2019 novel coronavirus (COVID-19) outbreak: a review of the current literature. EJMO 2020; 4: 1-7.

3. World Health Organization. https://www.who.int/emergencies/ diseases/novel-coronavirus-2019/question-and-answershub/q-a-detail/coronavirus-disease-covid-19 Site accessed on 10.05.2020.

4. Egloff MP, Ferron F, Campanacci V, Longhi S, Rancurel C, Dutartre $\mathrm{H}$, et al. The severe acute respiratory syndrome-coronavirus replicative protein nsp9 is a single-stranded RNA-binding subunit unique in the RNA virus world. Proc Natl Acad Sci 2004; 101: 3792-6.

5. Vennema H, Godeke GJ, Rossen J, Voorhout WF, Horzinek MC, Opstelten D, et al. Nucleocapsid-independent assembly of coronavirus-like particles by co-expression of viral envelope protein genes. The EMBO journal 1996; 15: 2020-8.

6. Du Toit A. Outbreak of a novel coronavirus. Nat Rev Microbiol 2020; 18: 123. 
7. Al-Maweri SA, Tarakji B, Shugaa-Addin B, Al-Shamiri HM, Alaizari NA, AlMasri O. Infection control: Knowledge and compliance among Saudi undergraduate dental students. GMS Hyg Infect Control 2015; 10: 10.

8. Singh A, Purohit BM, Bhambal A, Saxena S, Singh A, Gupta A. Knowledge, attitudes, and practice regarding infection control measures among dental students in Central India. J Dent Educ 2011; 75: 421-7.

9. Al-Shamiri HM, AlShalawi FE, AlJumah TM, AlHarthi MM, AlAli EM, AlHarthi HM. Knowledge, Attitude and Practice of Hepatitis B Virus Infection among Dental Students and Interns in Saudi Arabia. J Clin Exp Dent 2018; 10: 54-60.

10. Alharbi G, Shono N, Alballaa L, Aloufi A. Knowledge, attitude and compliance of infection control guidelines among dental faculty members and students in KSU. BMC Oral Health 2019; 19: 7.

11. Karcıoğlu Ö. What is Coronaviruses, and how can we protect ourselves? Phnx Med J 2020;2: 66-71.

12. Lorosa AH, Pereira CM, Hussne RP, Silva-Boghossian CM. Evaluation of dental students' knowledge and patient care towards HIV/AIDS individuals. Eur J Dent Educ 2019; 23: 212-9.

13. Myers JE, Myers R, Wheat ME, Yin MT. Dental students and bloodborne pathogens: occupational exposures, knowledge, and attitudes. J Dent Educ 2012; 76: 479-86.

14. Brondani M, Donnelly L. COVID-19 pandemic: Students' perspectives on dental geriatric care and education. J Dent Educ 2020; 84: 1237-44.

15. Quadri Mir FA, Jafer MA, Alqahtani AS, Al mutahar SAB, Odabi $\mathrm{NI}$, Daghriri AA, et al. Novel corona virus disease (COVID-19) awareness among the dental interns, dental auxiliaries and dental specialists in Saudi Arabia: A nationwide study. J Infect Public Heal 2020; 13: 856-64.

16. Atas $\mathrm{O}$, Yildirim TT. Evaluation of knowledge, attitudes, and clinical education of dental students about COVID-19 pandemic. Peer J 2020; 8: e9575

17. Bogoch II, Watts A, Thomas-Bachli A, Huber C, Kraemer MUG, Khan K. Pneumonia of unknown aetiology in Wuhan, China: potential for international spread via commercial air travel. J Travel Med 2020; 27: 8.

18. Lu H, Stratton CW, Tang YW. Outbreak of pneumonia of unknown etiology in Wuhan, China: The mystery and the miracle. J Med Virol 2020; 92: 401-2.

19. Sabino-Silva R, Jardim ACG, Siqueira WL. Coronavirus COVID-19 impacts to dentistry and potential salivary diagnosis. Clin Oral Investig 2020; 24: 1619-21.

20. Prati C, Pelliccioni GA, Sambri V, Chersoni S, Gandolfi MG. COVID-19: its impact on dental schools in Italy, clinical problems in endodontic therapy and general considerations. Int Endod J 2020; 53: 723-5.

21. Meng L, Hua F, Bian Z. Coronavirus Disease 2019 (COVID-19): Emerging and Future Challenges for Dental and Oral Medicine. J Dent Res 2020; 99: 481-7.

22. Hoda J. Identification of information types and sources by the public for promoting awareness of Middle East respiratory syndrome coronavirus in Saudi Arabia. Health Educ Res 2016; 31: 12-23.

23. Ge ZY, Yang LM, Xia JJ, Fu XH, Zhang YZ. Possible aerosol transmission of COVID-19 and special precautions in dentistry. J Zhejiang Univ Sci B 2020; 21: 361-8.

24. DeFrancesco L. Whither COVID-19 vaccines? Nat Biotechnol 2020; 38: 1132-45.

25. Ikhlaq A, Bint-E-Riaz H, Bashir I, ljaz F. Awareness and Attitude of Undergraduate Medical Students towards 2019-novel Corona virus. Pak J Med Sci 2020; 36: 32-6.

26. Coulthard P. Dentistry and coronavirus (COVID-19) - moral decision-making. Br Dent J 2020; 228: 503-5.

27. Peng $X, X u X, L i Y$, Cheng $L$, Zhou $X$, Ren B. Transmission routes of 2019-nCoV and controls in dental practice. Int J Oral Sci 2020; 12: 9.

28. Kearney RC, Premaraj S, Smith BM, Olson GW, Williamson AE, Romanos G. Massive Open Online Courses in Dental Education: Two Viewpoints: Viewpoint 1: Massive Open Online Courses Offer Transformative Technology for Dental Education and Viewpoint 2: Massive Open Online Courses Are Not Ready for Primetime. J Dent Educ 2016; 80: 121-7.

29. Cao W, Fang Z, Hou G, Han M, Xu X, Dong J, Zheng J. The psychological impact of the COVID-19 epidemic on college students in China. Psychiatry Res 2020; 287: 112934.

30. Talo Yildirim T, Dundar S, Bozoglan A, Karaman T, Dildes N, Acun Kaya $F$, et al. Is there a relation between dental anxiety, fear and general psychological status? PeerJ 2017; 5: 2978.

31. Divaris K, Mafla AC, Villa-Torres L, Sánchez-Molina M, GallegoGómez CL, Vélez-Jaramillo LF, et al. Psychological distress and its correlates among dental students: a survey of 17 Colombian dental schools. BMC Med Educ 2013; 13: 91.

32. Jowkar Z, Masoumi M, Mahmoodian H. Psychological Stress and Stressors Among Clinical Dental Students at Shiraz School of Dentistry, Iran. Adv Med Educ Pract 2020; 11: 113-20.

33. Milward MR, Cooper PR. Competency assessment for infection control in the undergraduate dental curriculum. Eur J Dent Educ 2007; 11: 148-54. 